\title{
PENERAPAN PERJANJIAN DALAM HUBUNGAN KERJA DAN PERLINDUNGAN HUKUM BAGI DRIVER ONLINE
}

\author{
Arikha Saputra, Muzayanah, Fitika Andraini \\ Fakultas Hukum, Universitas Stikubank (Unisbank) Semarang \\ Email : arikhasaputra@edu.unisbank.ac.id
}

\begin{abstract}
Abstrak
Transportasi dinilai sangat penting selain digunakan sebagai alat perpindahan orang maupun barang, transportasi pun berguna untuk mempercepat roda perekonomian, hal ini dikarenakan tanpa transportasi maka segala aktifitas akan terkendala sehingga mengakibatkan terkendalanya perekonomian. Ditandainya perubahan mengenai moda transportasi online, hal ini berdampak pula pada perkembangan dari sistem pekerjaan yang semula menggunakan sistem konvensional menjadi sistem aplikasi online.

Penelitian hukum ini mempergunakan pendekatan yuridis normatif. Spesifikasi penelitian menggunakan deskriptif analitis, penelitian ini diharapkan dapat memunculkan gambaran serta analisis, yang menyeluruh dengan secara sistematis mengenai kenyataan yang ada di lapangan khususnya mengenai tentang penerapan perjanjian hubungan kerja dan perlindungan sebagaimana yang terdapat di dalam perundang-undangan. Pengumpulan data dilakukan dengan cara melakukan observasi dan wawancara serta dengan menggunakan perundang-undangan yang berlaku.

Perjanjian kemitraan yang memiliki bentuk perjanjian sebagai perjanjian bagi hasil, perjanjian keagenan, dan perjanjian sub-kontrak. Sehingga sesuai dengan isi dari perjanjian kemitraan bahwa perusahaan transportasi online memposisikan pekerja atau driver sebagai mitra kerja dalam menjalankan kegiatan transportasi. Perjanjian hubungan kerja kemitraan tidak mengenal adanya atasan (majikan) dan bawahan seperti yang dikenal di dalam perjanjian kerja namun dalam perjanjian kemitraan semua pihak berada pada posisi yang sama kedudukannya. Dalam kegiatan transportasi online ialah perjanjian kemitraan yang memilki sifat kesetaraan para pihak sehingga dalam pelaksanaan unsur-unsur hubungan kerja yang terjadi ialah tidak berdasarkan dari pihak pertama atau pengusaha saja. Sehingga mengenai hubungan kerja yang menyebutkan bahwa terdapat unsur-unsur mengenai pekerjaan, upah dan perintah, mengenai ketiga hal unsur dalam hubungan kerja tidak memenuhi unsur-unsur yang terjadi pada perjanjian kemitraan antara perusahaan transportasi online dan driver.

Perlindungan yang didapati oleh pengemudi tertuang pada pasal 16 ayat 16 ayat (3) huruf $h$ dan i yakni mendapatkan kepastian santunan jika terjadi kecelakaan, dan kepastian mendapatkan perlindungan jaminan sosial ketenagakerjaan dan jaminan sosial kesehatan sesuai dengan ketentuan peraturan perundang-undangan walaupun dalam penerapannya pelasksaanaan perlindungan yang diberikan dengan menggunakan syarat disaat pengemudi melaksanakan kegiatan pengangkutan.
\end{abstract}


Kata Kunci : Perjanjian Kemitraan, Perlindungan Hukum, Transportasi Online

\begin{abstract}
Transportation is considered very important in addition to being used as a means of moving people and goods, transportation is also useful to accelerate the wheels of the economy, this is because without transportation, all activities will be constrained, resulting in economic constraints. Marked changes regarding the mode of online transportation, this also has an impact on the development of the work system that was originally using conventional systems to be an online application system.

This legal research uses a normative juridical approach. The specification of the research uses analytical descriptive, this research is expected to bring up a comprehensive picture and analysis systematically about the reality in the field, especially regarding the application of employment and protection agreements as contained in the legislation. Data collection is done by observing and interviewing and by using applicable laws.

Partnership agreements that have the form of agreements as profit sharing agreements, agency agreements, and sub-contract agreements. So that in accordance with the contents of the partnership agreement that online transportation companies position workers or drivers as work partners in carrying out transportation activities. The partnership agreement does not recognize the existence of a superior (employer) and subordinates as is known in the work agreement but in the partnership agreement all parties are in the same position. In online transportation activities is a partnership agreement that has the nature of the equality of the parties so that the implementation of the elements of the employment relationship that occurs is not based on the first party or the employer alone. So regarding the employment relationship which states that there are elements regarding employment, wages and orders, regarding the three terms the elements in the employment relationship do not meet the elements that occur in partnership agreements between online transportation companies and drivers.

The protection found by the driver is contained in Article 16 paragraph 16 paragraph (3) letters $h$ and $i$, namely obtaining certainty of compensation in the event of an accident, and certainty of obtaining employment social security and health social security protection in accordance with statutory provisions even though in the application of protection implementation which is given using conditions when the driver carries out transportation activities.
\end{abstract}

Keywords: Partnership Agreement, Legal Protection, Online Transportation 
Pendahuluan

Manusia yang secara hakekatnya diciptakan oleh Allah SWT sebagai mahluk sosial. Dimana manusia melakukan kegiatannya secara terus menerus serta dalam melakukan aktifitasnya yang cenderung membutuhkan akomodasi sebagai penunjang kebutuhan setiap saat. Dengan adanya akomodasi maka aktifitas dapat berjalan dengan lancar, sehingga perlu adanya transportasi yang dapat memberikan kemudahan dalam pelaksanaan pada kegiatan aktivitas masyarakat. Transportasi dinilai sangat penting selain digunakan sebagai alat perpindahan orang maupun barang, transportasi pun berguna untuk mempercepat roda perekonomian, hal ini dikarenakan tanpa transportasi maka segala aktifitas akan terkendala sehingga mengakibatkan terkendalanya perekonomian.

Moda transportasi darat mengalami perubahan dengan menyesuaikan kebutuhan zaman. Transportasi darat mengalami perubahan hal ini dikarenakan transportasi darat merupakan penopang terbesar dari kegiatan masyarakat Indonesia. Dengan demikian menandakan bahwa kegiatan transportasi menjadi sesuatu yang penting dalam segala kegiatan masyarakat. Masyarakat memerlukan transportasi sebagai sarana pendukung kegiatan dalam melakukan perpindahan benda maupun orang yang berada pada lokasi awal ke lokasi tujuan dengan mengunakan akomodasi kendaraan (Salim, 2000).
Transportasi darat di era saat ini mengalami transformasi baik berupa wujud dan sistem. Ditandainya perubahan mengenai moda transportasi online, hal ini berdampak pula pada perkembangan dari sistem pekerjaan yang semula menggunakan sistem konvensional menjadi sistem online. Dengan berkembangnya suatu teknologi memberikan perubahan pada hukum mengenai perjanjian. Perjanjian pada hakekatnya merupakan kebiasaan yang dilakukan oleh masyarakat, melalui perjanjian akan menimbulkan hak dan kewajiban yang sering disebut sebagai perikatan. Perjanjian merupakan suatu keterkaitan dengan perbuatan hukum salah satunya ialah tentang objek diantara kedua belah pihak, dimana satu pihak berjanji atau dianggap berjanji untuk melakukan sesuatu hal, sedang pihak lain menuntut pelaksanaan dari janji itu (Projodikoro, 1981).

Sebagaimana yang tertuang pada bunyi pasal 1313 Kitab Undang-Undang Hukum Perdata (KUHPER) yang menyebutkna tentang pengertian perjanjian yakni suatu perbuatan dengan mana satu orang atau lebih mengikatkan dirinya terhadap satu orang lain atau lebih. Dalam pembuatan perjanjian kerja dapat dilaksanakan dengan cara lisan maupun tertulis. Perusahaan transportasi melakukan perjanjian bersama dengan pekerjanya dapat berbentuk perjanjian dapat berbentuk perjanjian baku dan tertulis. Perjanjian baku dianggap sebagai ketentuan yang telah dibentuk atau 
disusun oleh perusahaan, yang terkadang membuat tidak ada pilihan dari driver online untuk melakukan perubahan terhadap perjanjian kerja yang telah dibuat oleh perusahaan sehingga terkadang merugikan bagi driver karena pengemudi hanya memiliki satu pilihan yakni dengan menyetujui atau tidak dari isi dari perjanjian yang dibuat secara sepihak (Muhammad, 1992).

Berdasarkan bunyi Pasal 27 ayat (2) Undang-Undang Dasar Negara Kesatuan Republik Indonesia Tahun 1945 yang mengamanatkan bahwa setiap warganegara memiliki hak atas pekerjaan dan penghidupan yang layak bagi kemanusiaan. Sehingga jelas dari amanat konsistusi negara bahwa setiap pekerja harus memperoleh perlakuan yang sama dengan didasari oleh keselamatan kerja berupa perlindungan terhadap pekerjanya. Namun pada perjanjian yang diterapkan oleh perusahaan jasa transportasi kepada pekerjanya terkadang masih belum memberikan bentuk perlindungan dalam bentuk keselamatan kerja kepada pekerjanya secara maksimal. Semestinya dengan melakukan perjanjian kemitraan yang disepakati oleh kedua belah pihak seharusnya dapat memberikan dampak keuntungan yang tidak hanya untuk perusahaan saja namun bagi pekerja pun juka ikut merasakan hal yang sama. Jika melihat dari kondisi yang ada perjanjian yang di buat oleh perusahaan penyedia jasa layaanan transportasi online tersebut telah menentukan secara sepihak terhadap isi maupun syarat yang harus dilakukan atau dipenuhi oleh pekerja. Sehingga dengan melihat hal demikian, pekerja sebagai subyek yang membutuhkan suatu pekerjaan tidak memiliki pilihan apapun kecuali menerima perjanjian tersebut dengan didasari keadaaan yang terpaksa.

Berdasarkan uraian diatas dapat ditarik suatu perumusan permasalahan yang timbul dalam penelitian ini adalah sebagai berikut

1. Bagaimanakah penerapan perjanjian hubungan kerja yang muncul bagi driver online?

2. Bagaimana perlindungan hukum yang diberikan kepada driver online dalam hubungan kerja?

\section{Metode Penelitian}

Penelitian tentang

"Penerapan Perjanjian Dalam Hubungan kerja dan Perlindungan Hukum Bagi Driver Online" menggunakan pendekatan yuridis normatif. Spesifikasi penelitian menggunakan deskriptif analitis, penelitian ini diharapkan dapat memunculkan gambaran serta analisis, yang menyeluruh dengan secara sistematis mengenai kenyataan yang ada di lapangan khususnya mengenai tentang penerapan perjanjian hubungan kerja dan perlindungan hukum., dengan melakukan pengumpulan data serta menggunakan peraturan perundang-undangan yang memiliki kaitannya dengan permasalahan mengenai perlindungan dan perjanjian hubungan kerja bagi driver online serta akan ditinjau pula dengan teori-teori di dalam hukum 
pengangkutan serta pengumpulan data dalam penelitian ini ditunjang dengan melakukan wawancara dan observasi.

\section{Pembahasan}

Penerapan perjanjian hubungan kerja yang muncul bagi driver online

\begin{tabular}{rrr}
\multicolumn{2}{r}{ Perjanjian $\begin{array}{r}\text { yang } \\
\text { sering } \\
\text { dikenal dalam bahasa } \\
\text { dikenal }\end{array}$ denganda } & sebutan
\end{tabular}
overeenkomstenrecht (Kansil, 2006). Perjanjian dikatakan sebagai salah satu sumber yang akan melahirkan suatu perikatan bagi para pihak yang melaksanakan dari suatu perjanjian. Dengan demikian dapat disimpulkan bahwa suatu perikatan merupakan perjanjian yang muncul dari suatu kesepakatan yang dibuat oleh para pihak baik secara bersama-sama maupun secara sepihak. Sebagaimana ditegaskan kembali dalam bunyi Pasal 1313 Kitab Undang-Undang Hukum Perdata yang menyebutkan bahwa perjanjian atau persetujuan adalah suatu perbuatan dengan mana satu orang atau lebih mengikatkan dirinya terhadap satu orang lain atau lebih. Sehingga jelas terlihat dari maksud yang terkandung pada bunyi Pasal 1313 Kitab UndangUndang Hukum Perdata (KUHPER) bahwa terjadinya perikatan dikarenakan telah diperolehnya izin atau kehendak (toestemming) dari mereka yang terikat dengan suatu perjanjian itu, yaitu mereka yang mengadakan kesepakatan atas perjanjian yang bersangkutan (Andasasmita, 1990).

Di dalam Kitab UndangUndang Hukum Perdata (KUHPER) mengenal azas dalam suatu perjanjian, yakni :

1. Azas Personalia Perjanjian, yakni perjanjian yang dibuat tidak diperbolehkannya mengadakan perjanjian atau pengikatannya selain untuk dirinya sendiri. Yang tertuang di dalam bunyi Pasal 1315 Kitab Undang-Undang Hukum Perdata (KUHPER).

2. Azas Kebebasan Berkontrak, dimana perjanjian yang dibuat berlaku sah bagi yang membuatnya. Dengan kata lain asas kebebasan berkontrak memberikan kebebasan kepada seseorang yang membuatnya untuk menentukan isi dan jenis perjanjuan yang akan disepakati oleh kedua belah pihak. Hal ini dikarenakan sifat dari hukum perjanjian menganut sistem terbuka karena hukum perjanjian memberikan keleluasaan kepada masyarakat untuk membuat suatu perjanjian dengan catatan tidak melakukan pelanggaran kesusilaan atau ketertiban umum (Subekti, 2002). Tertuang di dalam Pasal 1338 Ayat (1) Kitab Undang-Undang Hukum Perdata (KUHPER).

3. Azas Itikad Baik sebagaimana yang tertuang dalam bunyi Pasal 1338 ayat (3) Kitab UndangUndang Hukum Perdata (KUHPER) yang memberikan penegasan bahwa setiap perjanjian harus didasari dengan itikad baik. Itikad baik harus dilaksanakan kedua belah pihak dengan melakukan kejujuran serta tidak memiliki niat untuk membohongi pihak lainnya.

4. Azas Konsensualisme yakni asas ini memperjelas bahwa perjanjian 
yang dibuat secara bersama oleh para pihak telah terjadi atau terlahir bilamana para pihak menyepakati perjanjian tersebut sehingga perjanjian yang telah disepakati tersebut telah memiliki akibat hukum. Sebagaimana yang tertuang dalam Pasal 1320 Kitab UndangUndang Hukum Perdata (KUHPER) mengenai salah satu unsur yakni sepakat. Kesepakatan yang dilakukan oleh para pihak untuk bersama-sama tunduk pada perjanjian. Dengan membubuhkan tanda tangan oleh para pihak yang membuat suatu perjanjian maka dengan itulah para pihak menyepakati dan melekat mengenai substansi yang berupa isi, waktu, tempat yang sesuai dengan kesepakatan bersama.

5. Asas Pacta Sun Servanda dikenal sebagai pengikatan suatu perjanjian yang sebagaimana yang termaktub dalam Pasal 1338 Kitab Undang-Undang Hukum Perdata (KUHPER) yang menyatakan bahwa suatu perjanjian yang dibuat secara sah maka akan menjadikan pengikatan terhadap kedua belah pihak yang membuat perjanjian sehingga terdapat pengikatan yang harus dilakukan oleh keduanya ialah kewajiban dan hak.

Jika dilihat dari unsur perikatan yang muncul dari suatu perjanjian, maka dapat dikatakan bahwa driver online telah melakukan perikatan bersama dengan pihak perusahaan transportasi online, sebagaimana yang tercantum dalam bunyi Pasal 1313 Kitab Undang-
Undang Hukm Perdata yang menyebutkan bahwa perikatan lahir atau terjadi dikarenakan memperoleh izin atau kehendak dari pihak yang terikat dari perjanjian tersebut. Dengan adanya persetujuan atau kehendak dari para pihak maka telah terjadi hubungan hukum diantara keduanya. Hal ini didasari dengan driver online melakukan pendaftaran kepada pihak perusahaan transportasi online sehingga secara otomatis telah terjadi pengikatan secara hukum yang pastinya akan memunculkan kewajiban dan hak yang harus dipatuhi oleh kedua belah pihak.

Sebagaimana yang termaktub dalam Pasal 1320 Kitab UndangUndang Hukum Perdata (KUHPER) yang mengatur mengenai syarat sah perjanjian, yang membagi menjadi dua syarat yakni :

1. Syarat Subjektif

a. Kesepakatan

Perjanjian dapat dikatakan sah jika para pihak sepakat atau setuju mengenai segala kehendak yang telah disepakati secara bersamasama dengan cara memberikan persetujuan atau bersepakat apabila para pihak saling menghendaki terkait dengan perjanjian yang disepakati. Syarat subyektif menjadi hal yang menyangkut tentang para pihak dengan melakukan persesuaian kehendak mengenai berbagai pokok-pokok yang terdapat di dalam suatu perjanjian. Dalam syarat kesepakatan para pihak melakukan ikatan perjanjian dengan kemauan yang bebas dan sukarela untuk mengikatkan dirinya tanpa ada paksaan atau tekanan serta melakukan penipuan. 
Oleh karena itu, yang menjadi driver online haruslah melakukan pendaftaran diri sebagai pihak yang ingin melakukan hubungan kerja dengan perusahaan transportasi online dengan cara membuat akun dan sepakat atau menyetujui terkait mekanisme dari perjanjian yang telah disepakati bersama.

Melihat dari perjanjian yang dibuat antara driver dengan perusahaan jasa transportasi online dapat dikatakan perjanjian itu sah secara hokum hal ini dikarenakan perjanjian telah memperoleh kesepakatan dari para pihak, pengemudi pun telah memberikan persetujuan terhadap syarat dan ketentuan yang ditawarkan oleh pihak perusahaan sebagaimana yang tercantum di dalam perjanjian kemitraan dengan cara menyetujui persetujuan secara kontrak elektonik yang dilakukan dengan paksaan, penipuan kekhilafan, kesesatan atau kekeliruan.

b. Kecakapan

Pada unsur mengenai kecakapan lebih menitik beratkan pada tindakan atau perbuatan hukum dengan mengisyaratkan bahwa cakapnya seseorang atau pihak didasari dengan kedewasaan secara usia atau umur, telah menikah dan tidak dibawah pengampuan orang tua.

Syarat mengenai kecakapan dinilai sangat penting, hal ini dikarenakan sesorang yang hendak menjadi driver online harus memenuhi kriteria kecakapan mengenai usia, hal ini ditunjukkan dengan driver online harus memenuhi beberapa standar yang telah ditentukan oleh perusahaan jasa transportasi online yakni para driver harus mendaftar dengan menggunakan Kartu Tanda Penduduk (KTP) sebagai dasar untuk mengetahui admnistratif yang dikeluarkan secara sah oleh Dinas Kependudukan dan Catatan Sipil (Dispendukcapil) yang mana Kartu Tanda Penduduk dipergunakan untuk mengetahui batasan usia dari si driver serta driver yang dianggap cakap juga harus mampu menguasai kendaraan bermotor dan memiliki Surat Izin Mengemudi (SIM) yang dikeluarkan oleh pihak Kepolisian sebagai bukti pengemudi memiliki lisensi yang sah untuk mengemudikan dan mengendarai kendaraan bermotor dengan maksud dan tujuan sebagai kelengkapan berkendara, sebagai unsur keselamatan dijalan serta dipergunakan untuk melakukan kegiatan pemberian jasa pengangkutan sebagaimana yang telah ditentukan oleh penyedia jasa transportasi online dengan menggunakan aplikasi sebagai syarat para driver dapat melakukan pekerjaannya.

Dengan demikian, unsur mengenai kecakapan dianggap telah memenuhi persyaratan perundangundangan sebagaimana yang tertuang dalam Undang-Undang No 22 Tahun 2009 yang menyebutkan mengenai usia minimum seseorang dapat mengendarai kendaraan bermotor ialah usia 17 (tujuh belas) tahun, yang dianggap mampu menguasai dan mengambil tindakan saat mengendarai kendaraan bermotor.

2. Syarat Objektif

a. Hal (Objek) Tertentu

Berkaitan dengan hal tertentu lebih menitikberatkan kepada objek dari 
suatu perjanjian. Hal ini dikarenakan objek dalam suatu perjanjian menjadi suatu hal yang pokok dan harus ada dalam suatu perjanjian. Pelanggaran tentang syarat objek pada suatu perjanjian mengakibatkan perjanjian dinyatakan batal demi hukum (null and void). Sebagaimana yang tertuang di dalam pasal 1333 Kitab Undang-Undang Hukum Perdata (KUHPER) yang menyebutkan bahwa suatu perjanjian harus memiliki pokok dari suatu benda minimal dapat ditentukan jenisnya. Perjanjian yang dibuat haruslah memiliki objek tertentu sehingga dapat dikatakan bahwa sesuatu yang diperjanjikan harus terdapat hak dan kewajiban yang tertera di dalam perjanjian tersebut.

b. Klausal yang Halal

Syarat yang terakhir menitikberatkan pada penentuan klausa dan sebab. Sebagaimana yang tercantum di dalam pasal 1337 Kitab Undang-Undang Hukum Perdata (KUHPER) bahwa klausa halal ialah sesuatu yang menjadi sebab dari perjanjian yang dibuat tidak boleh bertentangan dengan undang-undang yang berlaku serta tidak melakukan pelanggaran terhadap norma kesopanan dan kesusilaan. Hal ini dikarenakan sebuah perjanjian pada akhirnya sebagai pencapaian tujuan bersama yang tidak boleh mengalami pelanggaran baik tentang pelanggaran yuridis maupun pelanggaran lainnya.

Berdasarkan perjanjian yang dibuat dan telah disepakati oleh kedua pihak maka telah mengacu pada ketentuan Kitab UndangUndang Hukum Perdata (KUHPER) sebagaimana yang termaktub dalam bunyi Pasal 1320 Kitab UndangUndang Hukum Perdata (KUHPER) mengenai syarat sah perjanjian, baik syarat subjektif maupun objektif. Namun apabila melihat dari sistem yang diterapkan oleh perusahaan jasa transportasi dengan driver yang menggunakan perjanjian kemitraan bukan menggunakan perjanjian kerja dalam melakukan hubungan kerjanya. Sehingga perlu adanya pemahaman mengenai perjanjian hubungan kerja kemitraan oleh para driver online. Perjanjian hubungan kerja kemitraan tidak mengenal adanya atasan (majikan) dan bawahan sebagaimana yang dikenal pada perjanjian kerja namun dalam perjanjian kemitraan semua pihak berada pada posisi yang setara kedudukannya, dikarenakan dalam hubungan kerja yang terjadi bukan perjanjian kerja yang sebagaimana diatur dalam Undang-Undang Nomor 13 Tahun 2003 tentang Ketenagakerjaan.

Jika berdasarkan UndangUndang Nomor 13 Tahun 2003 yang tercantum dalam Pasal 1 angka 15 yang menyebutkan mengenai hubungan kerja bahwa : "Hubungan kerja adalah hubungan antara pengusaha dengan pekerja atau buruh berdasarkan perjanjian kerja, yang mempunyai unsur pekerjaan, upah dan perintah". Serta hal mengenai Upah yang diatur pada Pasal 1 ayat 30 Undang-Undang Nomor 13 Tahun 2003 berbunyi sebagai berikut : "Upah adalah hak pekerja atau buruh yang diterima dan dinyatakan dalam bentuk uang sebagai imbalan dari pengusaha atau pemberi kerja kepada seluruh buruh atau pekerja yang ditetapkan 
dan dibayarkan menurut suatu perjanjian kerja, kesepakatan, atau peraturan perundang-undangan, termasuk tunjangan bagi pekerja atau buruh dan keluarganya atas suatu pekerjaan dan/atau jasa yang telah atau akan dilakukan".

Sehingga jika melihat dari penjelasan diatas mengenai hubungan kerja yang menyebutkan bahwa terdapat beberapa mengenai perintah kerja, klasifikasi pekerjaan dan pengupahan, mengenai ketiga hal unsur dalam hubungan kerja tidak memenuhi unsur-unsur yang terjadi pada perjanjian kemitraan antara perusahaan transportasi online dan pekerja. Perjanjian hubungan kerja yang terjadi di perusahaan jasa transportasi dan driver tidak dapat tunduk kepada Undang-Undang Nomor 13 Tahun 2003 tentang Ketenagakerjaan. Dikarenakan bahwa penerapan yang terjadi di dalam suatu perjanjian hubungan kerja di kedua pihak ialah perjanjian kemitraan atau perjanjian kerjasama. Perjanjian kemitraan merupakan perjanjian yang memiliki hubungan kerja yang kedudukannya sama atau setara sebagai mitra atau rekan kerja serta kedudukan dalam hubungan pekerjaan memilki keutamaan yang paling mendasar yakni saling menguntungkan di keduanya. Perjanjian kemitraan yang memiliki bentuk perjanjian sebagai perjanjian bagi hasil, perjanjian keagenan, dan perjanjian sub-kontrak. Sehingga sesuai dengan isi dari perjanjian kemitraan bahwa perusahaan transportasi online memposisikan pekerja atau driver sebagai mitra kerja dalam menjalankan kegiatan transportasi.
Dengan demikian jika melihat dari perjanjian yang terjadi dalam kegiatan transportasi online ialah perjanjian kemitraan yang memilki sifat kesetaraan para pihak sehingga dalam pelaksanaan unsurunsur hubungan kerja yang terjadi ialah tidak berdasarkan dari pihak pertama atau pengusaha saja. Unsur dalam hubungan kerja yang pertama mengenai pekerjaan bahwa pekerjaan yang dilakukan oleh driver online tidak diberikan ketentuan atau batasan untuk melakukan pekerjaan atau tidak selama masih dalam kategori yang disepakati bersama dalam perjanjian kemitraan. Hal ini dikarenakan driver online diberikan kebebasan untuk melakukan pekerjaannya, sehingga tidak diharuskan dalam perusahaan mengenai pelaksanaan pekerjaan dengan perintah serta tidak mengenal jam kerja sebagaimana yang diterapkan pada perusahaan pada umumnya. Driver tidak ada keterikatan dalam hal pelaksanaan pekerjaan kepada perusahaan sehingga berhak melakukan pekerjaan dengan jam waktu yang fleksibel.

Unsur yang kedua, ialah mengenai upah. Upah yang dimaksudkan dalam hubungan kerja pada Pasal 1 ayat 30 UndangUndang Nomor 13 Tahun 2002 jelas tidak sesuai hal ini dikarenakan upah yang didapati oleh para driver diperoleh dari imbalan atau pembayaran dari konsumen yang melakukan pememesanan atas kegiatan transportasi serta telah menyelesaikan kegiatan yang diminta oleh konsumen sesuai dengan aplikasi. 
Berdasarkan pada ketentuan pasal 15 ayat (1) Peraturan Menteri Perhubungan Republik Indonesia Nomor PM 12 Tahun 2019 tentang Perlindungan Keselamatan Pengguna Sepeda Motor Yang Digunakan Untuk Kepentingan Masyarakat yang menegaskan bahwa hubungan yang terjadi di dalam kegiatan pengangkutan trsansportasi berbasis online ialah "Hubungan antara Perusahaan Aplikasi dengan Pengemudi merupakan hubungan kemitraan". Hal ini juga ditegaskan pula pada penerapan hubungan dalam pelaksanaan kemitraan sebagaimana yang termaktub pada Pasal 12 Peraturan Pemerintah Republik Indonesia Nomor 44 Tahun 1997 tentang kemitraan yang berbunyi : "Usaha besar, usaha menengah dan usaha kecil yang melaksanakan kemitraan mempunyai hak sebagai berikut :

a. Meningkatkan efisiensi usaha dalam kemitraan

b. Mendapatkan kemudahan untuk melakukan kemitraan

c. Membuat perjanjian kemitraan, dan

d. Membatalkan perjanjian bila salah satu yang mengingkari

Dengan demikian berdasarkan hubungan yang terjadi sebagaimana yang termaktub dalam bunyi pasal diatas mengindikasi bahwa perjanjian yang berlaku ialah perjanjian kemitraan bukan perjanjian kerja sehingga dalam perjanjian kemitraan, perusahaan memiliki kewenangan untuk membuat perjanjian dan membatalkan perjanjian dengan menggunakan standar operasional pekerjaan dan prosedur yang jelas dalam melakukan penghentian operasional sementara (suspend) atau berakibat akhir pada putus mitra terhadap pengemudi yang melakukan kesalahan fatal terhadap konsumen sehingga mengakibatkan kerugian terhadap perusahaan, Hak ini ditegaskan dalam bunyi pasal 14 ayat (1) pada Peraturan Menteri Perhubungan Republik Indonesia Nomor PM 12 Tahun 2019 tentang Perlindungan Keselamatan Pengguna Sepeda Motor Yang Digunakan Untuk Kepentingan Masyarakat. Namun standar, operasional dan prosedur pemutusan mitra harus memuat beberapa ketentuan sebagaimana yang tertuang di dalam pasal 14 ayat (2) Peraturan Menteri Perhubungan Republik Indonesia Nomor PM 12 Tahun 2019 tentang Perlindungan Keselamatan Pengguna Sepeda Motor Yang Digunakan Untuk Kepentingan Masyarakat yakni sebagai berikut:

a. Jenis sanksi penghentian operasional sementara (suspend) dan putus mitra.

b. Tingkat pemberian sanksi penghentian operasional sementara (suspend) dan putus mitra.

c. Tahap pemberian sanksi penghentian operasional sementara (suspend) dan putus mitra.

d. Pencabutan sanksi penghentian operasional sementara (suspend).

Jika melihat dari Peraturan Pemerintah Republik Indonesia Nomor 44 Tahun 1997 tentang kemitraan, bahwa perusahaan berhak melakukan pemutusan atau pembatalan perjanjian kemitraan jika salah satu pihak melakukan 
kesalahan atau pengingkaran terhadap isi yang telah disetujuii oleh kedua belah pihak. Hal ini dibenarkan dengan pernyataan yang dikemukakan oleh salah satu pengemudi (online) yang menyebutkan bahwa sanksi yang diterima oleh para pengemudi yakni pemutusan hubungan kerja kemitraan atau penghentian operasional, namun sanksi tersebut diberikan atas dasar pada kesalahan yang diperbuat oleh pengemudi (driver) terhadap konsumen sehingga mengakibatkan kerugian kepada perusahaan jasa transportasi online, baik kerugian finansial ekonomi maupun kerugian nama baik perusahaan. Berdasarkan hasil wawancara dengan pengemudi (driver) menyebutkan bahwa tindakan dari sanksi pemutusan hubungan kemitraan berlaku apabila seorang driver merugikan konsumen seperti menolak konsumen, tidak melaksanakan sesuai dengan permintaan dari konsumen, menelantarkan konsumen dijalan terlalu lama, serta melakukan kecurangan terhadap perusahaan.

Penumpang dalam kegiatan transportasi merupakan konsumen dalam dunia pengangkutan. Hal ini dikarenakan penumpang merupakan salah satu bagian dari subyek dari pengangkutan dan penumpang juga merupakan pengguna dari jasa transportasi. Oleh karena itu kepuasan dari konsumen dalam transportasi merupakan salah satu indikator dari pelaksanaan pengangkutan yang diterapkan pada perusahaan jasa transportasi dengan ssstem online. Sebagaimana yang termaktub dalam Undang-Undang Nomor 8 Tahun 1999 tentang Perlindungan Konsumen yang salah satunya mengedepankan mengenai hak atas konsumen yakni hak atas kenyamanan, keamanan, dan keselamatan mengkonsumsi suatu barang dan/atau jasa. Maka dalam pemutusan hubungan kerja kemitraan salah satu indikatornya ialah melaksanakan kesalahan dalam pelaksanaan pengangkutan kepada konsumen dikarenakan hal ini mengadopsi hal yang berkaitan dengan hak konsumen yang telah dituangkan dalam Undang-Undang Nomor 8 Tahun 1999 tentang Perlindungan Konsumen.

\section{Perlindungan hukum yang diberikan kepada driver online dalam hubungan kerja}

Perlindungan hukum

memiliki keterkaitan dengan perolehan hak serta kewajiban dari subyek hukum itu sendiri. Subyek hukum yang dimaksud ialah manusia yang mempunyai hak serta kewajiban yang berkaitan dengan pelaksanaan kegiatan atau tindakan hukum yang dilakukannya.

Sebagaimana yang disebutkan oleh salah seorang driver online bahwa perlindungan yang diberikan kepadanya berupa pemberian asuransi kecelakaan, namun asuransi tersebut hanya dapat diberikan saat driver melaksanakan kegiatan pengangkutan baik barang maupun orang. Pemberian perlindungan yang diberikan oleh perusahaan transportasi kepada para pekerjanya harus berdasarkan pekerjaan yang dilakukannya. Perlindungan 
kecelakaan dapat didapatkan oleh pengendara jika sedang melakukan order pengantaran penumpang maupun barang. Namun seharusnya tidak hanya konsumen yang diberikan perlindungan hukum namun pengemudi pun seharusnya diberikan perlindungan dalam menjalankan kegiatannya, sehingga menjadi faktor keamanan dan keselamatan bagi pengemudi dalam menjalankan tugas yang memiliki resiko yang besar saat berada di jalan.

Perlindungan hukum bagi pengemudi (driver) yang menjadi mitra dari perusahaan jasa transportasi online dinilai masih perlu dimaksimalkan, hal ini dikarenakan pengemudi merupakan mitra yang seharusnya diberikan rasa keamanan dan keselamatan berupa perlindungan saat menjalankan aktivitasnya. Perjanjian yang tertulis dalam perjanjian antara perusahaan jasa transportasi online lebih menitik beratkan pada hak yang diberikan oleh perusahaan namun tidak memberikan akomodir mengenai berbagai kewajiban-kewajiban yang dilakukan oleh perusahaan jasa transportasi dalam pemberian proteksi kepada mitranya.

Berdasarkan definisi perlindungan hukum yakni memberikan pengayoman kepada hak asasi manusia yang dirugikan orang lain dan perlindungan tersebut diberikan kepada masyarakat agar mereka dapat menikmati semua hak yang diberikan oleh hukum. Oleh karenanya perlindungan hukum mutlak harus didadapatkan oleh setiap warganegara tanpa adanya pengecualian. Hal ini sebagaimana yang tertuang dalam Bab V mengenai Perlindungan Masyarakat pada pasal 16 menyebutkan bahwa "Perlindungan masyarakat dalam pelayanan penggunaan sepeda motor untuk kepentingan masyarakat diberikan terhadap penumpang dan pengemudi".

Perlindungan yang didapati oleh pengemudi berdasarkan dengan ketentuan Peraturan Menteri Perhubungan Republik Indonesia Nomor PM 12 Tahun 2019 tentang Perlindungan Keselamatan Pengguna Sepeda Motor Yang Digunakan Untuk Kepentingan Masyarakat sebagaimana yang tercantum di dalam Pasal 16 ayat (3) huruf h dan i yakni kepastian mendapatkan santunan jika terjadi kecelakaan, dan kepastian mendapatkan perlindungan jaminan sosial ketenagakerjaan dan jaminan sosial kesehatan sesuai dengan ketentuan peraturan perundang-undangan.

\section{Simpulan}

Berdasarkan hasil uraian dari hasil pembahasan mengenai "Penerapan Perjanjian Dalam Hubungan kerja dan Perlindungan Hukum Bagi Driver Online" dapat disimpulkan sebagai berikut :

1. Hubungan kerja antara pengemudi dengan perusahaan jasa transportasi online bukan sebagai perjanjian kerja namun penerapan perjanjian yang terjadi di dalam hubungan kerja antara perusahaan transportasi online dengan pegemudi ialah perjanjian kemitraan. Perjanjian kemitraan merupakan perjanjian yang memiliki 
hubungan kerja yang kedudukannya sama atau setara sebagai mitra atau rekan kerja serta kedudukan dalam hubungan pekerjaan memilki keutamaan yang paling mendasar yakni harus saling menguntungkan di keduanya. Dalam penerapan hubungan kerja antara pengemudi dan perusahaan transportasi tidak dapat tunduk pada UndangUndang Nomor 13 Tahun 2003 tentang Ketenagakerjaan dikarenakan tidak terpenuhinya unsur yang terdapat dalam perjanjian kerja yakni unsur upah dan perintah. Hal ini dikarenakan unsur upah yang didapatkan dari driver bukan berasal dari perusahaan melainkan dari konsumen yang menggunakan aplikasi pemesanan, dan unsur perintah yang terjadi bukan dari perintah atasan (perusahaan) secara langsung melainkan berdasarkan dari aplikasi yang diakses oleh konsumen.

2. Perlindungan hukum mutlak harus didadapatkan oleh setiap warganegara tanpa adanya pengecualian. Hal ini sebagaimana yang tertuang dalam Bab $\mathrm{V}$ mengenai Perlindungan Masyarakat pada pasal 16 menyebutkan bahwa "Perlindungan masyarakat dalam pelayanan penggunaan sepeda motor untuk kepentingan masyarakat diberikan terhadap penumpang dan pengemudi". Oleh karena itu Perlindungan yang didapati oleh pengemudi sebagaimana tertuang di dalam pasal 16 ayat
16 ayat (3) huruf h dan i yakni mendapatkan kepastian santunan jika terjadi kecelakaan, dan kepastian mendapatkan perlindungan jaminan sosial ketenagakerjaan dan jaminan sosial kesehatan sesuai dengan ketentuan peraturan perundang-undangan walaupun dalam penerapannya pelasksaanaan perlindungan yang diberikan dengan menggunakan syarat disaat pengemudi melaksanakan kegiatan pengangkutan.

\section{Daftar Pustaka}

Abbas Salim, 2000, Manajemen Transportasi, PT. Raja Grafindo Persada, Jakarta.

Abdulkadir Muhammad, 1992, Perjanjian Baku Dalam Praktek Perusahaan Perdagangan, Citra Aditya Bakti, Bandung.

Pengangkutan Niaga, Citra Aditya Bakti, Bandung.

Aloysius Uwiyono, 2014, Asas-Asas Hukum Perburuhan, RajaGrafindo Persada, Jakarta.

B.N. Marbun, 1997, Manajemen Perusahaan Kecil, PT. Pustaka Binaman Pressindo, Jakarta.

Cholid Narbuko dan Abu Achmadi, 2001, Metodologi Penelitian, Bumi Aksara, Jakarta.

Christine kansil, 2013, Pokok-Pokok Pengetahuan Hukum Dagang Indonesia, Sinar Grafika, Jakarta Timur.

C.S.T. Kansil, 2006, Modul Hukum Perdata Termasuk Asas-Asas 
Hukum Perdata, PT. Pradnya Paramita, Jakarta.

Hasyim, Farida, 2009, Hukum Dagang, Sinar Grafika, Jakarta.

H.M.N.

Purwosutjipto,1984,

Pengertian Pokok Hukum

Dagang Indonesia Jilid 3

Hukum Pengangkutan,

Djambatan, Jakarta.

J.S.Badudu dan Sutan Mohammad, 1994, Kamus Umum Bahasa Indonesia, PT. Integraphic, Jakarta.

Komar Andasasmita, 1990, Notaris II Contoh Akta Otentik Dan Penjelasannya, Cetakan 2, Ikatan Notaris Indonesia Daerah Jawa Barat, Bandung.

Muchtaruddin Siregar, 1990, Beberapa Masalah Ekonomi dan Manajemen Pengangkutan, Lembaga Penerbit FE UI, Jakarta.

Satjipto Rahardjo, 1996, Ilmu Hukum, Cet IV, PT Citra Aditya, Bandung.

--on, 2000, Ilmu Hukum, Cetakan V, Citra Aditya Bakti, Bandung.

Soerjono Soekanto, 1984, Pengantar Penelitian Hukum, Universitas Indonesia Press, Jakarta.

Faktor Yang Mempengaruhi Penegakan Hukum, Raja Grafindo Persada, Jakarta.

Soerjono Soekanto dan Sri Sri Mamuji, 2006, Penelitian Hukum Normatif Suatu Tingkatan, Cet ke 9, Rajawali Press, Jakarta
Subekti, 2002, Hukum Perjanjian, Intermas, Bandung.

Suharnoko, 2004, Hukum Perjanjian, : Prenada Media, Jakarta.

Sution Usman Adji, Djoko Prakoso dan Hari Pramono, 1991, Hukum PengangkutanIndonesia, Rineka Cipta, Jakarta.

Thee Kian Wie, 1992, Dialog Kemitraan dan Keterkaitan Usaha Besar dan Kecil dalam Sektor Industri Pengolahan, Jakarta : Gramedia.

Wijaya C, 2009, Makalah Perencanaan Angkutan Umum, Sipil UI.

Wirjono Projodjodikoro, 1981, AzasAzas Hukum Perjanjian, Bandung: P.T. Bale Bandung.

Zainal Asikin, 2016, Hukum Dagang, Rajawali Pers, Jakarta.

\section{Perundang-Undangan}

Kitab Undang-Undang Hukum Perdata (KUHPER)

Undang-Undang Nomor 8 Tahun 1999 tentang Perlindungan Konsumen

Undang-Undang Nomor 13 Tahun 2003 tentang Ketenagakerjaan

Undang-Undang Nomor 22 Tahun 2009 tentang Lalu Lintas dan Angkutan Jalan (UULLAJ

Peraturan Menteri Perhubungan Republik Indonesia Nomor PM 12 Tahun 2019 tentang Perlindungan Keselamatan Pengguna Sepeda Motor Yang Digunakan Untuk Kepentingan Masyarakat

Peraturan Pemerintah Republik Indonesia Nomor 44 Tahun 1997 tentang kemitraan 
Nomor 44 Tahun 1997

tentang kemitraan 